\title{
The Italian Julian Alps - A new Biosphere Reserve for a sustainable future
}

\author{
Stefano Santi, Paola Cigalotto \& Alessandro Benzoni
}

Keywords: biosphere reserve, cultural heritage, protected area, transboundary

\section{Abstract}

In June 2019 UNESCO established the new Italian Julian Alps Biosphere Reserve $(B R)$ in the frame of the MAB programme. It includes the entire territory of 11 mountain municipalities in the Friuli Venezia Giulia region. The recognition is based on the special biodiversity of the area, its original historical and cultural characteristics, and the possibility of creating a new transboundary BR with the Slovenian Julian Alps. Ongoing projects dedicated to nature preservation, awareness raising on environmental topics, the promotion of typical local products and the involvement of the local community were also judged positively. The BR is seen by local administrators and stakeholders as an opportunity to develop actions for sustainability with regard to the protection and enhancement of the extraordinary environmental richness, and to give young people the opportunity to live in the area. For this reason, the Management Committee will be supported in its activity by a Youth Advisory Board.
Profile

Protected area

Italian Julian Alps

Biosphere Reserve

Mountain range

Alps, Italy

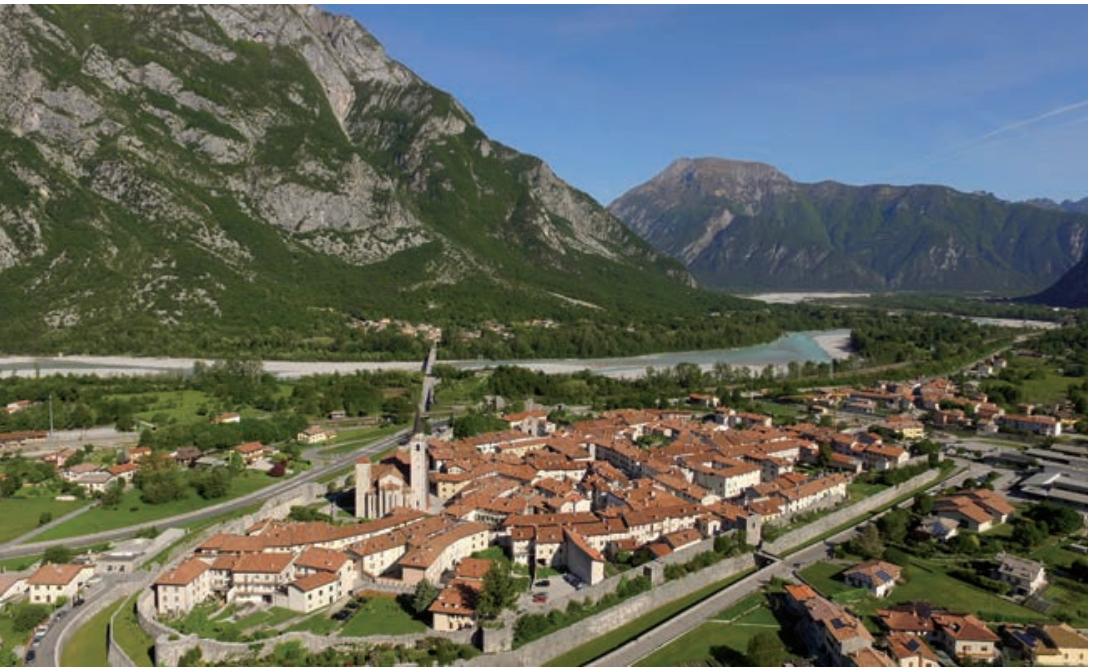

Figure 1 - Venzone and the river Tagliamento. (C) MoviTex

\section{Introduction}

On 19 June 2019, the area comprising 11 municipalities in the far north-eastern part of Italy was named the Italian Julian Alps Biosphere Reserve (BR) within the framework of UNESCO's MAB programme, becoming the $19^{\text {th }} \mathrm{BR}$ in Italy, and marking the end of a process which had begun in 2011 and developed over 8 long years of meetings and discussions involving many different stakeholders.

The Italian Julian Alps BR covers about $715 \mathrm{~km}^{2}$ and includes the municipalities of Artegna, Chiusaforte, Dogna, Gemona del Friuli, Lusevera, Moggio Udinese, Montenars, Resia, Resiutta, Taipana and Venzone in the Autonomous Region of Friuli Venezia Giulia (see Figure $1 \& 2$ ). The BR is situated close to Austria, and for several kilometres it shares a border with Slovenia. About 22000 people live in the area.
Within the space of a few kilometres, the elevation profile passes from approximately $150 \mathrm{~m}$ above sea level on the Osoppo - Gemona Plain to $2754 \mathrm{~m}$ on Mount Jof di Montasio. The rainfall pattern in the $\mathrm{BR}$ is one of the most abundant in Europe, often reaching annual averages in the Musi Mountains of 2800-3000 $\mathrm{mm}$. The area includes two important watersheds, belonging to two great rivers in the southeastern part of the Alpine arc: the Tagliamento and Isonzo-Soča, which both flow into the Northern Adriatic Sea and act as primary ecological corridors linking the Alpine arc and the sea.

The recognition of the area as a BR has its origins in the extraordinary natural, landscape and cultural characteristics of the region, but the history, territorial management model, existing projects, and involvement of the younger generations all played their part. Also important was the strong pre-existing link with the neighbouring Julijske Alpe MAB BR in Slovenia, and it is hoped that in the not too distant future this will lead to the creation of just one transboundary BR in the Julian Alps. This perspective was also highly appreciated by the International Co-ordinating Council of the Man and the Biosphere Programme.

A peculiar characteristic of the region is the key role it plays as a link between different landscapes, ecosystems and cultures. These overlappings and intertwinings have contributed to the creation of a plural environment, the specificity and uniqueness of which combine with the differences that are also found here: above all, this is a transitional territory between the Latin and Slavic worlds; it is also a strategic hub between the mountainous Alpine and Prealpine environments and the great plain context. The succession of elevations present different landscapes and habitats associated with particular climatic characteristics, and specific ways of life: from glaciers to Alpine land- 


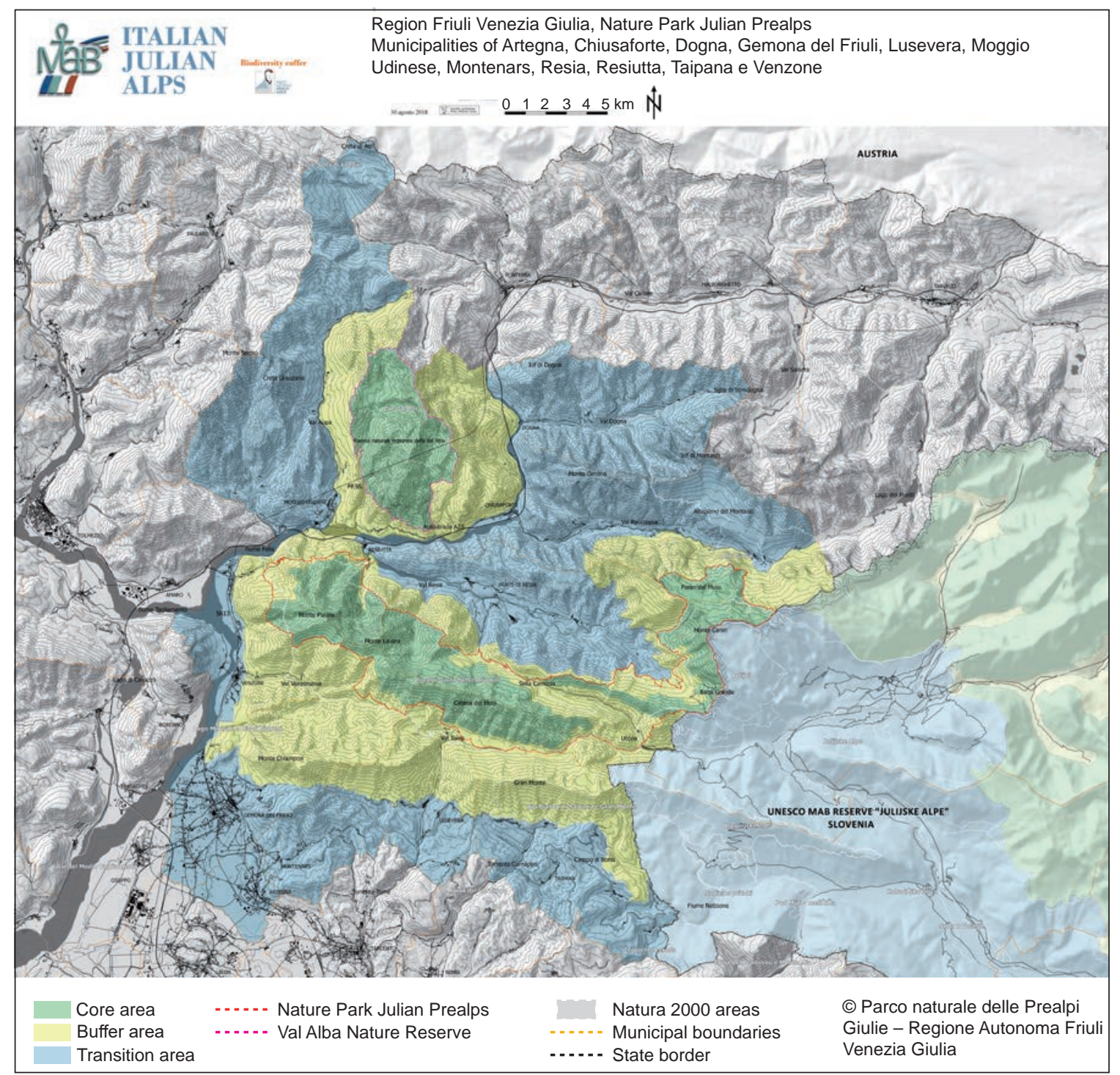

Figure 2 - Zonation map of the Italian Julian Alps Biosphere Reserve

scapes dotted with Malgas (mountain farms) and cottages, wooded slopes scattered with pastures, to larger settlements on the plains.

The Julian Alps are characterized by three main aspects: extremely high biodiversity, an extraordinary cultural mix, and communities with a high level of resilience who, over time, have never ceased to fight proudly to preserve and protect their territory and culture.

\section{A wealth of biodiversity}

The specific biological nature of the BR is determined by several factors: its biogeographic location, elevation gradient and abundant rainfall are particularly relevant. The richness of nature in the area has been confirmed by several studies (Genero et al. 1998; Mainardis 2001; Museo Friulano di Storia Naturale 2004; Gobbo \& Poldini 2005), and constant monitoring activities.
From a natural-environmental point of view, the conservation of landscapes, ecosystems, species and genetic variability is guaranteed by the presence, within the area's boundaries, of several officially-managed protected areas, as well as a high density of sites belonging to the Natura 2000 Network.

The peculiar biogeographical and bioclimatic characteristics are directly reflected in the chorological spectrum of the area, in which there is a prevalence of Eurosibiric elements (Cypripedium calceolus L., Malva sylvestris L. subsp. sylvestris), while there are also others of a Mediterranean-Mountain corotype (Genista radiata (L.) Scop., Gentiana clusii E.P. Perrier \& Songeon subsp. clusii) alongside strictly Alpine species (Eryngium alpinum L., Luqula alpina Hoppe), which are also wellrepresented.

Within the area, there are numerous rare and endemic floristic species (Campanula zoysii Wulfen., Physoplexis comosa (L.) Schur.) as well as fauna species (Austropotamobius pallipes Lereboullet, Rosalia alpina L., 


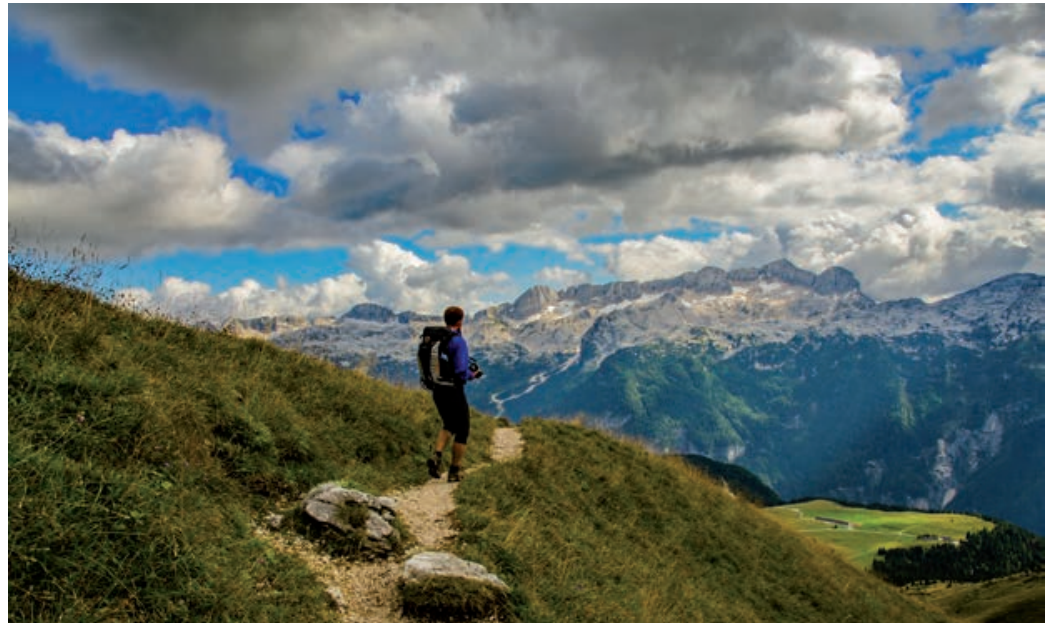

Figure 3 - Canin Massif (C) Archivio PNPG - Marco Di Lenardo

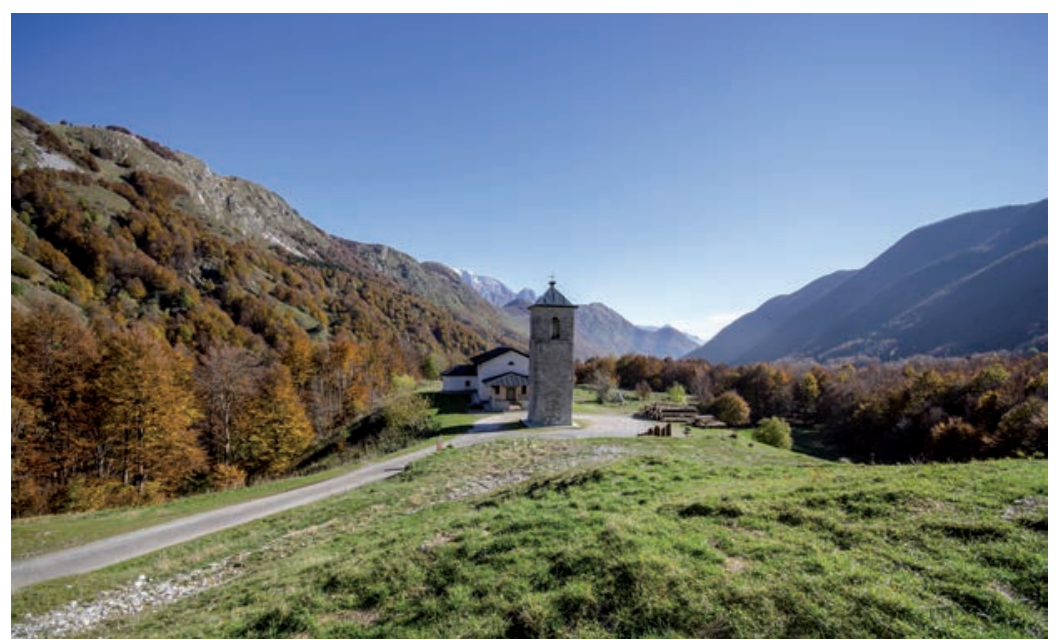

Figure 4 - Saint Ann in Carnizza (C) Archivio PNPG - Marco Di Lenardo eas have confirmed the presence of an extraordinary floristic variety (see Regione Autonoma Friuli Venezia Giulia 2018).

The area is also characterized by a wide variety of habitats that provide suitable sites for the reproduction, nutrition and growth of fauna whose biodiversity is just as rich as that of the flora, ranging from large carnivores to invertebrates. The fundamental role of the entire area as an Alpine corridor is proven by the way large carnivores, including brown bears, pass frequently from the Slovenian Julian Alps to those on the Italian side. Just as important is the autumnal migration of the avifauna monitored at the bird-ringing station in Malga Confin (Venzone).

The significance of these phenomena has been attested by various projects, and by the recognition of the region as an Alpine pilot area for ecological connectivity, carried out in collaboration with the equivalent authority on the Slovenian side, and conferred by the Secretariat of the Alpine Convention.

\section{Land of water and rocks}

The BR represents perhaps the largest water basin in the Friuli Venezia Giulia region and in this part of the Alps: at one end, there is the region's only glacier, situated on Mount Canin, and at the other, on the Campo di Osoppo plains, between Gemona and Artegna, is the largest underground freshwater reservoir, which supplies the Central Friuli area. In the mountain and pre-Alpine areas, the karstic soil, which absorbs surface water, has led since ancient times to the invention of techniques to collect and manage water (cisterns, fountains, springs), as it is a scarce resource. Similarly, on the plain, a large portion of arid, gravelly soil led to the creation of an ancient system of canals to supply the fields, mills and manufacturing activities.

On the south-western edge of the BR flows the unspoilt Tagliamento river. Water has shaped this territory profoundly, partly because of the richness of the geology in the area, which includes significant geosites (Cucchi et al. 2009). The Karst morphology extends to the Foran dal Mus plateau, at the foot of Mount Canin, where it is at its richest. Here all types of surface and underground Karst phenomena can be found. Particularly impressive is the area near Col delle Erbe, where hundreds of the caves are located, including the Gortani Abyss, which is over $900 \mathrm{~m}$ deep. The Grotta Nuova in Villanova extends for $8020 \mathrm{~m}$ and is open to visitors and for excursions.

\section{Cultural diversity: one land, many voices}

The territory of the BR is an age-old crossroads where different cultures and populations have met, as proven by the presence of a multitude of dialects and languages, varied settlement patterns, and the variety of agricultural and artistic practices. Cultural diversity is considered of paramount importance on an internabands. The management plans for the Natura 2000 ar- 
tional scale: here, the interplay between the Latin world and the Slavic world takes on forms that still have to be examined in detail, although they were already the subject of anthropological studies in the $19^{\text {th }}$ century. In particular, research would be welcome regarding the Resia Valley, in the heart of the BR, from ethnographical, linguistic and musicalogical points of view (Adaïewsky 1883 in Guzzi 2012). The area is particularly interesting linguistically, because the ancient Resian language is still used here.

The overlapping of cultures can be seen in the castles, wayside stones, architecture of the settlements and other physical features in those places in particular which saw flows of international migrants from north to south and from east to west passing through them. In Roman times, Roman power came up against Noricum (a territory corresponding to most of modern-day Austria and part of Slovenia); the customs station in Resiutta constituted a point of transition between these two worlds. Later, the Abbey in Moggio Udinese, built in the $11^{\text {th }}$ century, was the Patriarchate of Aquileia, in the Alpine area of which it became a fief with the right to vote in the Friuli General Parliament. In turn, the two medieval centres of Venzone and Gemona del Friuli bear witness to the flows of people who transited through this area from north to south and back again, and still do so today, as they are key points of contact between the mountains and the plain (Floramo 2017).

\section{Resilience and capacity of adaptation}

A feature of the communities in the area that is by no means secondary is their capacities of resilience and adaptation, seen in their ability to adapt to the succession of wars, changing administrative boundaries, the different powers and forms of government, and extreme weather conditions. The resilience shown in the local communities' response to the 1976 earthquake, which had its epicentre in this very territory, causing devastating damage, appears to be of great importance both today and for the future. Reconstruction after the earthquake was a true example of a bottom-up process: local communities played an important role both in promoting a reconstruction process that respected local identities and in the definition of an emergency management system, mostly carried out on a voluntary basis, which led the way on a global level. The Italian Civil Protection Service was founded here (see link below: Tiere Motus museum).

Since the effects of global warning have become evident, particular - urgent - efforts need to be made to allow nature and man to co-exist in this area, and further research needs to be carried out. The melting of icecaps, the decreasing reliability of snow, and extreme weather conditions form a scenario of global reference that has repercussions also in the Julian Alps and imposes modifications in local management and development strategies.

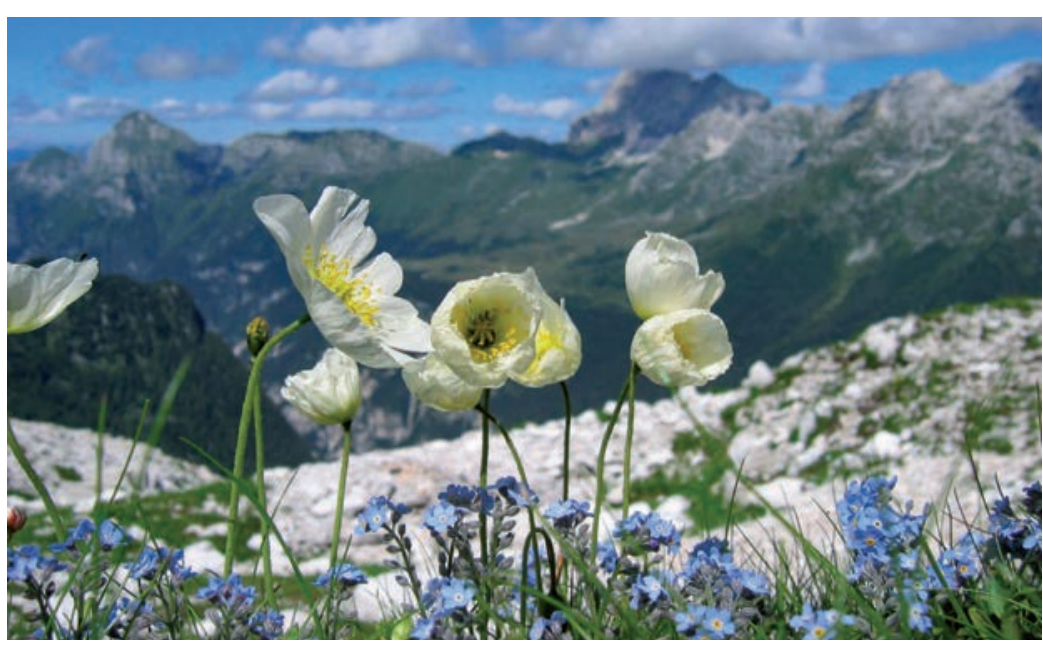

Figure 5 - Julian Alps poppies (C) Elena Mattiussi

\section{The biosphere reserve's main goal}

The main goal of the BR is to drive and lead local people towards a future of sustainability, in the belief that only a path based on environmental wealth can provide those who wish to remain in this area with the concrete possibility of doing so. This goal is strongly shared by local administrations, Ecomuseums, NGOs and private associations representing local communities that actively participated in the application process to become a BR. The objective of establishing a BR is to promote a vision which will achieve sustainable development anchored to the values of the territory, and in line with the themes developed by the Alpine Convention: quality of life in the Alpine area, tourism and production zones, agriculture, animal husbandry and forestry, energy self-sufficiency and the Alpine ecological network.

\section{A host of projcets to be developed}

Within the boundaries of the BR, a variety of activities have been established in order to achieve sustainable development. Many activities are carried out both by the municipal authorities and by the widespread network of associations and local players, including the Ecomuseum of Waters and the Resia Valley Ecomuseum (see links below).

Among the many projects developed, some are particularly worthy of note as they have greater significance and relevance in relation to the 2016-2025 Lima Action Plan, the 2015-2025 MAB Strategy, and the 2030 Agenda for Sustainable Development. These projects include:

preserving biodiversity thanks to the monitoring and active management activities carried out in the area, and thanks to EU funding;

reducing the impact of $\mathrm{CO}_{2}$ emissions through the calculation of the carbon footprint in the Gemona del Friuli area;

reinforcing local identity through the creation of Parish maps by the Ecomuseums; 

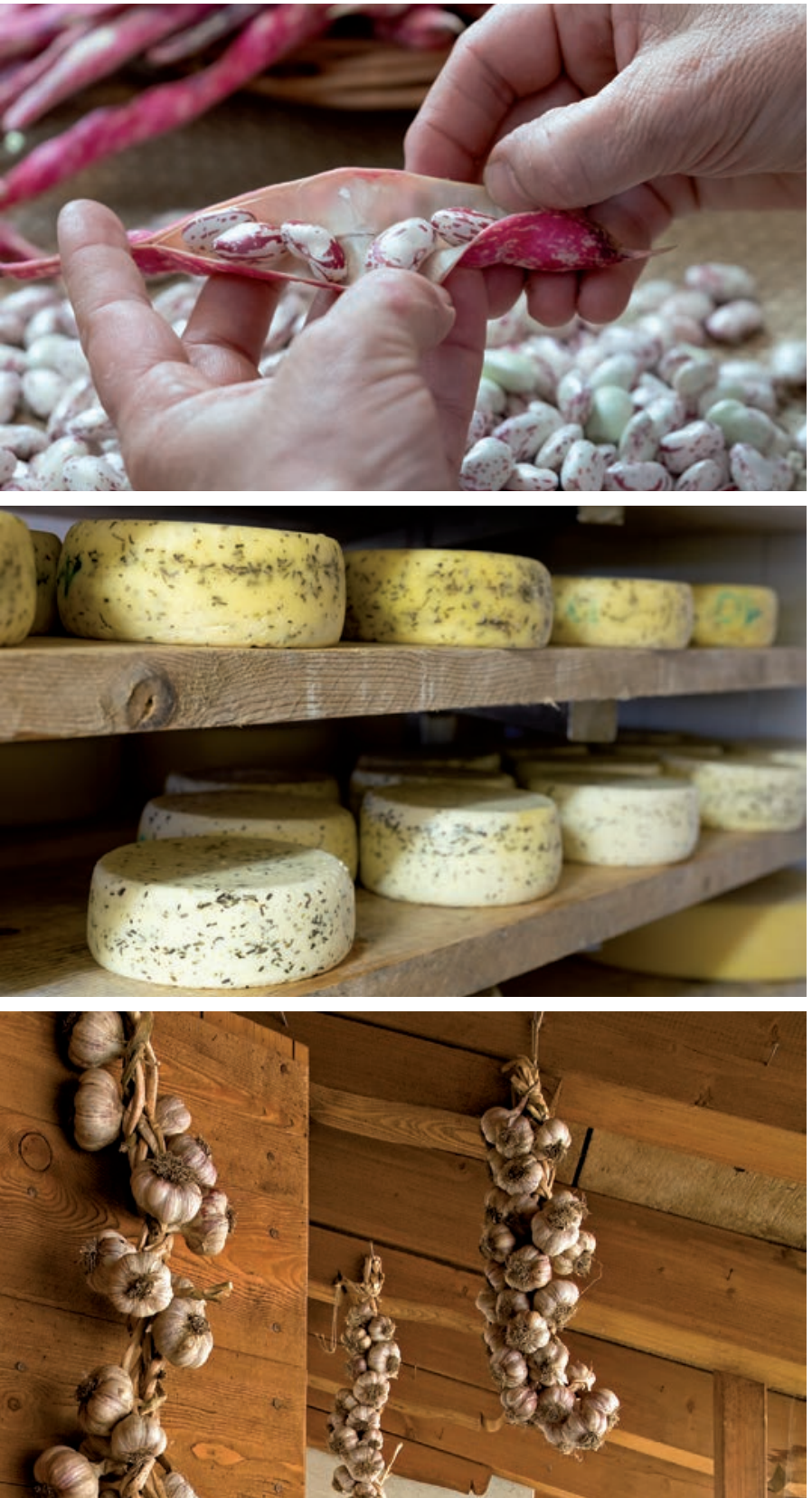

Figure 6 - The local Fiorina bean (top), mountain cheese (middle) and Resia garlic (bottom). (C) Paolo Da Pozzo

implementing responsible consumption and production in agriculture, including the conservation and valorization of prestigious local products (pumpkins, garlic, bread, flour, truffles ...) which have led to the recognition of three Slow Food presidia (Resia Garlic, Pan di Sorc - corn bread, and Latteria Turnaria cheese) (ERSA 2008) (Figure 6);

implementing sustainable tourism through a wide selection of outdoor activities, including cycling tours, developed especially around the international Alpe Adria cycle route, and an extensive footpath network for walking and hiking (see Figure 3); activities promoting health, well-being and healthy lifestyles by means of the Sportland intermunicipal project, managed by Gemona - the city of well-being.
This brief list should be enough to help us understand the direction in which this territory is going. In the near future, these projects will be both carried forward and enhanced. Others identified in the Management Plan / Action Plan will be launched. In particular, the process to establish the MAB cross-border BR in the Julian Alps will be initiated, in agreement with the Slovenian authorities.

\section{Participatory management for an active biosphere reserve}

With the aim of constantly involving the local stakeholders, the management of the BR will be as participatory as possible. The Management Committee will decide the guidelines to be followed in order to reach the BR goals. The Committee consists of 17 members, 11 of whom are the Mayors of the municipalities involved. The Julian Prealps Regional Nature Park will perform a coordination function for the entire BR and its activities. The Management Committee will be joined by three advisory bodies:

1. the Committee for Associations and Economic Categories;

2. the Youth Advisory Board;

3. the Technical-Scientific Committee.

Their role will be to support the Management Committee in pursuing the aims of the BR and to ensure co-operation between its communities, associations and stakeholder groups. More specifically, the Technical-Scientific Committee will have 5 representatives coming both from the Universities and the Natural History Museums of Udine and Trieste, as well as the domain of culture. Its task will be to provide opinions and formulate proposals on issues of the greatest technical and scientific interest, taking into account the objectives relating to the establishment of the BR. It will also verify the coherence of the actions undertaken in the light of these objectives alongside the general guidelines of the MAB programme.

What appears to be even more strategic for the future is the involvement of the young residents so that they become the driving force behind the BR. The Youth Advisory Board of the BR, open to all residents aged between 16 and 30, was established for this very purpose. It will have a consultative and propositional function in the decision-making processes regarding the BR and will foster the active participation of young people in the initiatives. It will not only encourage relations between young people in the municipalities of the BR but will also actively participate in the drafting of projects involving young people in relation to BRs.

The role of the younger generations will be part of the great challenge to achieve the success of the entire initiative: the involvement of the local communities. The challenge is to ensure that every inhabitant feels ownership of the BR, and has the power to change the trends taking place in this part of the Alps. Only 
in this way will the BR be seen as offering a future, based on its exceptional natural and cultural heritage, to those who want to live there.

\section{References}

Crichiutti, G. 1906. Elenco di piante raccolte per la prima volta in Valle di Raccolana e nel gruppo del monte Canin con cenno sulla distribuzione delle piante arboree. Atti della Accademia Scientifica Veneto-Trentino-Istriana 3(1-2): 104-121. Padova. [In Italian]

Cucchi, F., F. Finocchiaro \& G. Muscio 2009. Geositi del Friuli Venezia Giulia, Arti Grafiche Friulane - Udine

ERSA 2008. Cibario del Friuli Venezia Giulia - Atlante dei Prodotti della Tradizione, Editoriale Ergon s.r.l. (GO) [In Italian]

Floramo, A. 2017, Forse non tutti sanno che in Friuli... Roma. [In Italian]

Genero, F. 1998. Piano pluriennale di gestione della fauna del Parco naturale delle Prealpi Giulie. Ente parco naturale delle Prealpi Giulie - Resia. [In Italian]

Gobbo, G. \& L. Poldini 2005 La diversità floristica del Parco naturale delle Prealpi Giulie, Ente parco naturale delle Prealpi Giulie - Resia. [In Italian]

Guzzi, F. 2012. Un voyage a Resia. Il manoscritto di Ella Adaiewsky del 1883 e la nascita dell'etnomusicologia in Europa. [In Italian]

Julian Prealps Nature Park Authority 2018. Italian Julian Alps, a biodiversity coffer - Biosphere reserve nomination form.

Mainardis, G. 2001 Atlante illustrato della Flora del Parco delle Prealpi Giulie. Ente parco naturale delle Prealpi Giulie - Resia. [In Italian]

Museo Friulane di Storia Naturale 2004. Monitoraggio di invertebrati bioindicatori di pascoli e faggete. Ente parco naturale delle Prealpi Giulie - Resia. [In Italian]

Poldini, L. 1991. Atlante corologico delle piante vascolari nel Friuli-Venezia Giulia. Inventario floristico regionale. Regione Autonoma Friuli - Venezia Giulia - Direzione Regionale Foreste e Parchi, Università di Trieste. [In Italian]

Regione Autonoma Friuli Venezia Giulia 2018. La rete europea Natura 2000 per la tutela della biodiversità. Available at: http://www.regione.fvg.it/rafvg/cms/ RAFVG/ambiente-territorio/tutela-ambiente-gestione-risorse-naturali/FOGLIA203/FOGLIA132/ [In Italian]

Simonetti, G. \& G. Mainardis 1997 Carta della vegetazione delle Prealpi Giulie nord-occidentali tra il fiume Tagliamento ed il gruppo del Monte Canin. Arti Grafiche Friulane - Tavagnacco (Ud). [In Italian]
Links

Ecomuseo delle Acque del Gemonese: http:// www.ecomuseodelleacque.it/ecomuseo-en

Tiere Motus museum in Venzone: http://www.tieremotus.it/en

Val Resia Ecomuseum: http://www.tarvisiano.org/ Ecomuseums/Val-Resia-Ecomuseum

\section{Authors}

Stefano Santi ${ }^{1}$ - corresponding author

has been Director of the Julian Prealps Regional Nature Park since 2004 and has been examining environmental issues and questions of sustainable development for about 30 years. He graduated in agricultural sciences from the University of Udine, after which he worked as an agronomist and taught for a number of years in high schools. He is currently a member of the Europarc (the European Parks Federation) cross-border protected areas steering committee and working group and verifier of the European Charter for Sustainable Tourism. E-mail: stefano.santi@parcoprealpigiulie.it

\section{Paola Cigalotto²}

is an architect and urban planner, and was an Adjunct professor with teaching and research responsibilities in the Department of Engineering and Architecture, University of Trieste (2001-2019). The author of General City Plans, Town plans, Masterplans, papers and books about urban planning and architecture, she has received several awards for her work on sustainable design and planning. E-mail: paola.cigalotto@ gmail.com

\section{Alessandro Benzoni ${ }^{1}$}

is head of the administrative office of the Julian Prealps Nature Park. He graduated in law from the University of Trieste and has been President of the Italian Alpine Club, Tolmezzo section, since 2015. He deals with environmental issues both professionally and in his leisure time. He is a lover of mountains in all their aspects, and practises mountaineering, climbing and ski mountaineering.

${ }^{1}$ Ente parco naturale delle Prealpi Giulie, Piazza del Tiglio 3, 33010 Resia, Italy, info@parcoprealpigiulie.it ${ }^{2}$ Architecture, landscape and urban planning, Via della Prefettura 8. 33100 Udine, Italy. 